University of Nebraska - Lincoln

DigitalCommons@University of Nebraska - Lincoln

Generation and validation of genetic markers for the selection of carioca dry bean genotypes with the slow-darkening seed coat trait

\author{
Renata C. Alvares \\ Robert Stonehouse \\ Thiago L.P.O. Souza \\ Patrícia G.S. Melo \\ Phillip N. Miklas
}

See next page for additional authors

Follow this and additional works at: https://digitalcommons.unl.edu/usdaarsfacpub

Part of the Agriculture Commons

This Article is brought to you for free and open access by the U.S. Department of Agriculture: Agricultural Research Service, Lincoln, Nebraska at DigitalCommons@University of Nebraska - Lincoln. It has been accepted for inclusion in Publications from USDA-ARS / UNL Faculty by an authorized administrator of DigitalCommons@University of Nebraska - Lincoln. 


\section{Authors}

Renata C. Alvares, Robert Stonehouse, Thiago L.P.O. Souza, Patrícia G.S. Melo, Phillip N. Miklas, Kirstin E. Bett, Leonardo C. Melo, Luana A. Rodrigues, Lorena L. Souza, and Helton S. Pereira 


\title{
Generation and validation of genetic markers for the selection of carioca dry bean genotypes with the slow-darkening seed coat trait
}

\author{
Renata C. Alvares $\cdot$ Robert Stonehouse - Thiago L. P. O. Souza - Patrícia G. S. Melo • \\ Phillip N. Miklas • Kirstin E. Bett • Leonardo C. Melo • Luana A. Rodrigues • \\ Lorena L. Souza $\cdot$ Helton S. Pereira
}

Received: 14 March 2019/Accepted: 1 July 2019/Published online: 16 July 2019

U.S. government works are not subject to copyright.

(C) Springer Nature B.V. 2019

\begin{abstract}
Slow darkening (SD) is a trait that helps to maintain a brighter seed coat appearance in certain market classes of dry beans. The aim of this study was to generate new fluorescence-based markers and validate previously identified microsatellite markers for linkage to the SD trait in lines of the carioca market class. Four segregating populations were generated by Embrapa, the Brazilian Agricultural Research Corporation, from crosses between the SD cultivar BRSMG Madrepérola and the regular-darkening cultivars BRS Estilo, BRS Cometa, BRS Notável and BRS Sublime. These populations were screened with the simple-sequence markers Pvsd1158 and PVM02TC116 and with a TaqMan ${ }^{\mathrm{TM}}$ marker designed for the single-nucleotide polymorphism (SNP) PvbHLHp12804. A KASP marker was
\end{abstract}

R. C. Alvares · P. G. S. Melo · L. L. Souza

Universidade Federal de Goiás, Goiânia, Goiás, Brazil

R. Stonehouse · K. E. Bett

Department of Plant Sciences, University of

Saskatchewan, Saskatoon, SK S7N 5A8, Canada

T. L. P. O. Souza · L. C. Melo · L. A. Rodrigues ·

H. S. Pereira $(\bowtie)$

Embrapa Arroz e Feijão, Santo Antônio de Goiás, Goiás, Brazil

e-mail: helton.pereira@embrapa.br

P. N. Miklas

Grain Genetic and Physiological Research Unit, USDA-

ARS, Prosser, WA, USA also designed for the PvbHLHp12804 marker for testing on advanced carioca lines developed by the University of Saskatchewan. In the carioca lines developed by Embrapa, PVM02TC116 proved unsuitable for marker-assisted selection (MAS). Both the Pvsd-1158 and PvbHLHp12804 markers were found to be tightly linked to the gene responsible for the SD trait, with genetic distances calculated at $2.8 \mathrm{cM}$ for Pvsd-1158 and 2.0 and 3.1 cM for PvbbHLHp12804, respectively. These markers presented more than $97 \%$ of selection efficiency. The genotypic scoring using the PvbHLHp12804 KASP marker was perfectly correlated with the phenotype in all lines of the University of Saskatchewan. The results of this study validates the use of Pvsd-1158 as a gel-based marker for SD in carioca beans. The new fluorescence-based SNP PvbHLHp12804 markers exhibited very tight linkage to SD in carioca and pinto bean lines. These markers will be ideal for MAS for the SD trait in these market classes.

Keywords Phaseolus vulgaris $\cdot$ Marker assisted selection $\cdot$ SNP $\cdot$ SSR

\section{Introduction}

Dry beans (Phaseolus vulgaris L.) are grown extensively throughout Brazil, which is currently one of the 
largest dry bean-producing countries in the world. In 2016, 2.7 million metric tonnes of dry beans were produced in Brazil on 1.9 million ha (Embrapa Arroz e Feijão 2018). The carioca market type represents $70 \%$ of the Brazilian consumer market (Pereira et al. 2012a). Seed appearance, in particular seed coat color, is the most critical aspect that affects consumer preference. A seed coat or testa with a light creamcolored background with light brown streaks is the color of choice. Darker-colored seeds lead to consumer dissatisfaction and rejection based on the belief that such seeds are older and therefore more difficult to cook due to hardened seed coats (Junk-Knievel et al. 2008; Couto et al. 2010).

Environmental and genetic factors influence darkening of the seed coat (Junk-Knievel et al. 2008; Silva et al. 2008, 2014; Elsadr et al. 2011; Araújo et al. 2012; Alvares et al. 2016). Environmental conditions, such as excessive moisture during harvest and high humidity and temperature during storage, promote darkening of the seed coat (Siqueira et al. 2014).

Germplasm with reduced darkening of the seed coats has been observed in pinto (Singh et al. 2006) and carioca germplasm (Silva et al. 2008). Inheritance studies conducted by Junk-Knievel et al. (2008) and Silva et al. (2008) in pinto and carioca dry bean market classes, respectively, revealed monogenic recessive control of the slow-darkening trait. The gene for seed darkening in pinto bean was named $S d$, with the recessive allele $s d$ representing the slowdarkening condition (Junk-Knievel et al. 2008). Elsadr et al. (2011) subsequently reported that $S d$ influences the speed of bean seed darkening (i.e. slows darkening) and that another gene, $J$, conditions whether the seed will darken (dominant) or not (i.e. non-darkening when recessive). The non-darkening $J$ is epistatic to the slow-darkening $s d$. Similarly, Silva et al. (2014) also reported that seed coat darkening in carioca bean is influenced by more than one gene. Although the selection of breeding lines and the development of cultivars (Bett et al. 2014; Alvares et al. 2016; Osorno et al. 2017) with the slow-darkening trait has been relatively straightforward given its high heritability and simple genetics (Junk-Knievel et al. 2008; Silva et al. 2008, 2014; Araújo et al. 2012), the slowdarkening trait is maternally expressed and recessively inherited, whereby identification of seeds with the trait is delayed until the $F_{3}$ generation, which slows breeding progress. Therefore, multiple plant breeding programs have worked towards identifying linked markers to expedite the development of cultivars with the slow-darkening trait. Despite this effort, however, reports on the application of marker-assisted selection (MAS) for the slow-darkening trait in carioca breeding programs are generally lacking.

Couto et al. (2010) identified three microsatellite markers (PVM02TC116, X57022 and PVESTBR-98) closely linked to a quantitative trait locus that controlled seed coat darkening in $F_{2: 3}$ progeny derived from a cross between the carioca cultivars BRSMG Madrepérola (slow darkening) and BRSMG Majestoso (regular darkening). Felicetti et al. (2012) used two pinto bean populations developed from crosses with slow-darkening breeding lines derived from two different sources, SDIP-1 and 1533-15, to develop two gel-based simple-sequence repeat (SSR) markers (Pvsd-1157 and Pvsd-1158) that were tightly linked to the slow-darkening locus. These authors reported that the use of these markers to identify the slowdarkening trait in carioca bean was promising, but they only tested a few carioca lines with the slowdarkening trait derived from pinto bean.

Mapping the SSR markers Pvsd-1157 and Pvsd1158 in the CDC Pitium/1533-15 pinto bean RIL population placed the slow-darkening locus on chromosome Pv07 (Felicetti et al. 2012). The SSR markers also co-segregate with the $P$ locus (Bett and Miklas, unpublished data); a central ground factor for seed coat color. Indeed, a BLAST search revealed that the Pvsd-1157 and Pvsd-1158 marker sequences were located near the physical location of the $P$ gene. During the characterization of white seed color (McClean et al. 2018), the exon regions of the $P$ gene were sequenced from various types of common bean, including three slow-darkening pinto beans (CDC WM-2, Pinto Saltillo and SDIP) and two regular-darkening pinto beans (CDC Pintium and Winchester). While the exon sequences for $P$ for the three slow-darkening beans were identical, and the sequences for the two regular-darkening beans were identical, there were several polymorphisms between the two groups. Fluorescence-based assays were then designed to detect one of these polymorphisms, a single-nucleotide polymorphism (SNP) designated PvbHLHp12804.

The objective of this study was to evaluate the effectiveness of this new SNP marker PvbHLHp12804 and that of the most tightly linked SSR markers Pvsd- 
1158 and PVM02TC116 from previous studies for MAS of the slow-darkening trait in carioca breeding populations.

\section{Materials and methods}

Carioca populations segregating for the slow darkening trait

The Common Bean Breeding Program conducted by Embrapa, the Brazilian Agricultural Research Corporation, has developed four carioca inbred populations that segregate for slow-darkening seed coat, upright plant architecture and high seed yield, with the trials conducted in the field by the bulk method (Silva et al. 2018). These populations were derived from crosses between the slow-darkening cultivar BRSMG Madrepérola (Carneiro et al. 2012) and four regular-darkening cultivars: BRS Estilo (Melo et al. 2010), BRS Sublime (Wendland et al. 2018), BRS Cometa (Faria et al. 2008) and BRS Notável (Pereira et al. 2012b) (Table 1). All of these cultivars were developed by Embrapa. A total of 54-56 $F_{5: 6}$ lines were randomly selected for evaluation from each population and grown in three separate field trials. Each trial was composed of 220 lines and the five parents in a $15 \times 15$ lattice design, with individual plots consisting of two 3-m rows. Two trials had three replications and one had two replications. One trial was planted in Santo Antônio de Goiás and two were planted in Brasília DF, with all three trials conducted during the 2012 winter growing season. Fertilization was applied based on soil analysis recommendations, and normal procedures for bean crop treatments (herbicides, insecticides) in the growing region were followed, except for disease control, which was not performed.

Advanced carioca breeding lines with the slowdarkening trait

The Dry Bean Breeding Program at the University of Saskatchewan developed four slow-darkening carioca parental lines: 3707CBB, 2862CBB-3, 2994CBB-10 and 3326CBB-5. All four of these carioca lines trace their slow-darkening seed coat trait back to SC117433 , a slow-darkening pinto breeding line (Junk-Knievel et al. 2008). Several crosses were made using $3707 \mathrm{CBB}$ and $2862 \mathrm{CBB}-3$ as the slow-darkening donor to generate populations of advanced carioca lines with the slow-darkening trait combined with improved agronomic performance. Selected slowdarkening lines were advanced to the $F_{2: 6}$ generation with phenotypic selection for slow darkening at each generation. Fourteen $F_{2: 6}$ advanced lines were selected randomly from these two populations for marker assays, and 16 seeds from each of the 14 lines were subsequently selected randomly for genotyping. At least 30 seeds from the four parental lines, i.e. 3707CBB, 2862CBB-3, 2994CBB-10 and 3326CBB5 , were also randomly selected for genotypic evaluation. Seeds from A285, a regular-darkening carioca line from CIAT (International Center for Tropical Agriculture, Cali, Colombia), were included as a check in the marker assay.

Phenotyping the slow-darkening trait

After harvest, samples of the Embrapa populations were stored in transparent plastic bags and kept at ambient temperature and humidity for 90 days on shelves constructed in a threshing shed located at the Embrapa Arroz e Feijão institution (Santo Antônio de Goiás, Brazil). The scoring scale proposed by Silva et al. (2008) was adopted for the evaluation of seed darkening; this scale ranges from 1 (very light-colored carioca seed coat background) to 5 (very dark seed coat background). Those lines with a mean value of $\leq$ 2.5 were considered to be slow-darkening lines, and those lines with a mean value of $>2.5$ were considered to be regular-darkening lines (Couto et al. 2010).

Darkening of the seed samples at the University of Saskatchewan was accelerated using the UV light protocols developed by Junk-knievel et al. (2007). CDC Pintium (regular darkening) and CDC WM-2 and KVxUI-1 (both slow darkening) were used as checks. Only one side of the seed was darkened to allow pre- and post-treatment comparison.

\section{DNA samples}

For each line screened with the TaqMan ${ }^{\circledR}$ assay, young leaf tissue was combined from ten greenhousegrown, 20-day-old seedlings. DNA was extracted using Invisorb ${ }^{\circledR}$ Spin Plant Mini kits (Stratec, Berlin, Germany) following the instructions recommended by the manufacturer. The total amount of genomic DNA was estimated using the NanoDrop 2000 UV-Vis 
Table 1 Common bean cultivars of the carioca commercial class developed by Embrapa that were used to obtain segregating populations for seed darkening, and their respective traits

\begin{tabular}{|c|c|c|c|c|c|c|c|c|c|}
\hline Cultivar & Genealogy & $\begin{array}{l}\text { Seed } \\
\text { darkening }{ }^{\mathrm{a}}\end{array}$ & $\begin{array}{l}\text { Plant } \\
\text { architecture }^{\mathrm{b}}\end{array}$ & $\begin{array}{l}100 \\
\text { seed } \\
\text { weight }^{\mathrm{c}}\end{array}$ & Cycle $^{\mathrm{d}}$ & Anthracnose & $\begin{array}{l}\text { Common } \\
\text { bacterial } \\
\text { blight }\end{array}$ & $\begin{array}{l}\text { Anglular } \\
\text { leaf spot }\end{array}$ & $\begin{array}{l}{ }^{\text {h}} \text { Fusarium } \\
\text { wilt }\end{array}$ \\
\hline $\begin{array}{l}\text { BRSMG } \\
\text { Madrepérola }\end{array}$ & $\begin{array}{l}\text { AN512666-0/ } \\
\text { AN73001 }\end{array}$ & S & $\mathrm{P}$ & 24 & SE & MS & S & MS & $\mathrm{S}$ \\
\hline BRS Sublime & $\begin{array}{l}\text { EMP250/4/ } \\
\text { A769//I } \\
\text { A429/ } \\
\text { XAN252// } \\
\text { V8025/ } \\
\text { PINTO UI } \\
114\end{array}$ & $\mathrm{R}$ & $\mathrm{U}$ & 25 & $\mathrm{~N}$ & MS & $\mathrm{S}$ & MR & $\mathrm{S}$ \\
\hline BRS Estilo & $\begin{array}{l}\text { EMP250/4/ } \\
\text { A769/// } \\
\text { A429/ } \\
\text { XAN252// } \\
\text { V8025/ } \\
\text { PINTO UI } \\
114\end{array}$ & $\mathrm{R}$ & $\mathrm{U}$ & 26 & $\mathrm{~N}$ & MS & S & S & S \\
\hline BRS Cometa & $\begin{array}{l}\text { A769/5/ } \\
\text { EMP250/4/ } \\
\text { A429/ } \\
\text { XAN252// } \\
\text { V8025/ } \\
\text { G4449/// } \\
\text { WAF2/ } \\
\text { A55//GN31/ } \\
\text { XAN170 }\end{array}$ & $\mathrm{R}$ & $\mathrm{U}$ & 24 & SE & $\mathrm{R}$ & S & $\mathrm{S}$ & S \\
\hline BRS Notável & $\begin{array}{l}\text { A769/5/A774/ } \\
\text { 4/A429/ } \\
\text { XAN252// } \\
\text { V8025/ } \\
\text { G4449/// } \\
\text { WAF2/ } \\
\text { A55//GN31/ } \\
\text { XAN170 }\end{array}$ & $\mathrm{R}$ & $\mathrm{U}$ & 24 & SE & $\mathrm{R}$ & MR & S & MR \\
\hline
\end{tabular}

R, Resistant; MR, moderately resistant; MS, moderately susceptible; S, susceptible

${ }^{\text {a }} \mathrm{S}$, Slow; R, regular

${ }^{\mathrm{b}} \mathrm{P}$, Prostrate; U, upright

${ }^{\mathrm{c}} 100$ seed weight (g/100 seeds)

${ }^{\mathrm{d}} \mathrm{SE}$, Semi-early maturity; N, normal maturity

spectrophotometer (Thermo Scientific, Waltham, MA, USA), and $10 \mathrm{ng} \mu \mathrm{L}^{-1}$ stocks were created by dilution with autoclaved Milli-Q water.

For material screened with the KASP (kompetitive allele-specific PCR) assay, a modified CTAB extraction (Doyle and Doyle 1990) was used to extract DNA from leaf tissue or a crude extraction was used to isolate DNA directly from cotyledon tissue of ungerminated seeds. For the crude extraction, a small section of the seed coat was removed, and a toothpick was used to scrape and collect a small amount of cotyledon tissue. The isolation protocol followed these steps: addition of $10 \mu \mathrm{l}$ of $0.25 \mathrm{M} \mathrm{NaOH}$, gentle mixing and then incubation at room temperature for $2 \mathrm{~min}$, followed by the addition of $15 \mu \mathrm{l}$ of $0.5 \mathrm{M}$ Tris (pH 8.0), gentle mixing and then incubation at room 
temperature for $2 \mathrm{~min}$. Extracted materials were either stored in the fridge (if used shortly after the isolation procedure) or in the freezer (for longer term storage). DNA from crude extractions was not quantified, but the extractions were diluted $10 \times$ in water for use in KASP reactions.

\section{Existing marker assays}

The PCR reactions, amplification profiles and gel electrophoresis were performed as described by Felicetti et al. (2012) and Couto et al. (2010) for markers Pvsd-1158 and PVM02TC116, respectively, with $58{ }^{\circ} \mathrm{C}$ of annealing time. The primer sequences are described in Table 2.

New marker generation and assay

Two different fluorescent-based marker types, namely a TaqMan ${ }^{\circledR}$ (Applied Biosystems ${ }^{\mathrm{TM}}$, Foster City, CA, USA) assay and a KASP (LGC Group, London, UK) assay, were designed to detect the SNP PvbHLH12804 (Table 2). The TaqMan ${ }^{\circledR}$ assay was used to screen the carioca parents and the BRSMG Madrepérola $\times$ BRS Estilo, BRS Sublime, BRS Cometa and BRS Notável populations.

Sample-to-SNP Allelic Discrimination PCR was performed with the Taqman ${ }^{\circledR}$ GTXpress ${ }^{\mathrm{TM}}$ Master Mix (Life Technologies, Carlsbad, CA, USA) in a 384-well plate. The final volume of the reaction mixture $(5.0 \mu \mathrm{L})$ contained: $2.5 \mu \mathrm{l}$ Taqman ${ }^{\circledR}$ GTXpress $^{\mathrm{TM}}$ Master Mix, $0.125 \mu \mathrm{l} 40 \times$ assay mix, $1.375 \mu \mathrm{L}$ Milli-Q $\mathrm{H}_{2} \mathrm{O}$ and $1.0 \mu \mathrm{L}$ lysate DNA. Plates were sealed with adhesive films and briefly centrifuged (5000 $g, 30 \mathrm{~s})$. The PCR program was performed in a QuantStudio 7 Flex Real Time PCR System (Applied Biosystems) and consisted of $60{ }^{\circ} \mathrm{C}$ for $30 \mathrm{~s}, 95^{\circ} \mathrm{C}$ for $20 \mathrm{~s}, 50$ cycles of $95^{\circ} \mathrm{C}$ for $3 \mathrm{~s}$ and $60{ }^{\circ} \mathrm{C}$ for $30 \mathrm{~s}$, with a final extension of $60{ }^{\circ} \mathrm{C}$ for $30 \mathrm{~s}$. Analysis of the genotyping results was performed using the Genotyping Analysis Module V3.7 of QuantStudio.

A KASP assay was used to screen advanced carioca lines in the University of Saskatchewan breeding program. KASP assays were performed in a final volume of $5.0 \mu \mathrm{L}$ using 384-well plates and a Low Rox master mix as a passive reference dye. Biallelic discrimination was achieved through the competitive binding of two allele-specific forward primers, one labeled with FAM dye and the other with HEX dye. PCR reactions were performed following manufacturer's instructions using $100 \mathrm{ng}$ of DNA mixed with $2.5 \mu \mathrm{L}$ Master Mix, $0.07 \mu \mathrm{L}$ assay mix and $2.43 \mu \mathrm{L}$ lysate DNA. Plates were sealed with adhesive films and briefly centrifuged (5000 $g, 30 \mathrm{~s})$. The PCR program was performed in a QuantStudio 7 Flex Real Time PCR System and consisted of $30{ }^{\circ} \mathrm{C}$ for $1 \mathrm{~min}$, $90{ }^{\circ} \mathrm{C}$ for $15 \mathrm{~min}, 10$ cycles of $94{ }^{\circ} \mathrm{C}$ for $20 \mathrm{~s}$ and $61{ }^{\circ} \mathrm{C}$ for $60 \mathrm{~s}, 26$ cycles of $94{ }^{\circ} \mathrm{C}$ for $20 \mathrm{~s}, 55^{\circ} \mathrm{C}$ for $60 \mathrm{~s}$, with a final extension step of $30{ }^{\circ} \mathrm{C}$ for $60 \mathrm{~s}$.

\section{Statistical analysis}

Individual analyses of variance per trial and joint analysis of variance were performed, with the effect of lines considered to be random and that of environments to be fixed. The degrees of freedom of treatments and the genotype-by-environment

Table 2 Primer sequences of microsatellite markers Pvsd-1158 and PVM02TC116 and the PvbHLH12804 single-nucleotide polymorphism marker identified as linked to the $s d$ gene that controls common bean seed coat darkening

\begin{tabular}{ll}
\hline Marker & Primer sequence \\
\hline Pvsd-1158 & Forward: GCAATTGACAAAAAGCTTCG \\
PVM02TC116 & Reverse: TTGTCATGCGGTTTT \\
& Forward: CGCCATTTGGATTGGATT \\
PvbHLH12804 & Reverse: AGGCGTGGAAGTGGAGTG \\
& A1: GAAGGTGACCAAGTTCATGCTCCACGTGCTCGCGGAGCG \\
& A2:GAAGGTCGGAGTCAACGGATTACCACGTGCTCGCGGAGCA \\
& C: GACCAGTGACCGCAGGATTACGAA \\
\hline
\end{tabular}

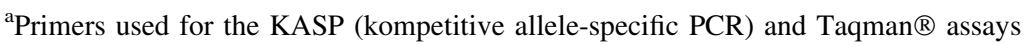


interaction were decomposed in the sources of variation due to the four populations under study.

Phenotypic segregation of seed darkening and genotypic segregation of the markers were evaluated using the Chi-square $\left(\chi^{2}\right)$ test to test the hypothesis of an expected segregation of 0.53 regular darkening (RD):0.47 slow darkening (SD) for the populations, taking into consideration the generation of obtaining lines $\left(F_{5}\right)$ and a single gene controlling bean seed darkening, with dominance of the allele that confers regular darkening (segregation of 3RD:1SD in $F_{2}$ ). The progenies were evaluated in the $F_{5: 6}$ generation; however, bean seed darkening is evaluated by observing the seed coat. As in a seed, the embryo is the product of fertilization and the seed coat is a maternal tissue, the generation of the seed coat effectively evaluated was in the $F_{5}$ generation.

The Chi-square test and determination of the recombination frequency and the genetic distances between the markers and the target locus were carried out using the program Genes/GQMol (Cruz 2013). Estimation of the genetic distances adopted the LOD value $=3.0$ and recombination frequency $r=0.30$. The recombination frequency was converted to centiMorgans (cM) using the mapping distance of Kosambi (1944). In addition, selection efficiency was estimated for each marker, based on comparison between the phenotypic and genotypic data, using the estimator proposed by Silva et al. (2007).

\section{Results and discussion}

Phenotypic segregation of the populations

Individual analyses of variance and joint analysis for seed darkening in lines developed by Embrapa showed significant differences between the parents and among lines within the four segregating populations, thereby confirming the reports by Alvares et al. (2016) that genetic variability exists for the slow-darkening trait in these populations. The high $(>85 \%)$ broad heritability estimates indicated that a major gene was likely responsible for a large part of the phenotypic variation. Based on the joint analysis results, among the parents, BRSMG Madrepérola exhibited lightercolored seed coats (1.4) compared to the regulardarkening parents BRS Estilo (3.2), BRS Sublime (3.0), BRS Cometa (4.3) and BRS Notável (4.2).
The joint analysis revealed that the BRSMG Madrepérola $\times$ BRS Sublime and BRSMG Madrepérola $\times$ BRS Estilo populations did not fit the expected 0.53 RD:0.47 SD monogenic segregation pattern expected for $\mathrm{F}_{5}$ derived lines whereby slow darkening is conditioned by a single recessive allele (Table 3). Segregation distortion in these populations could be caused by sampling biases or the differential viability of gametes (Carneiro and Vieira 2002), as well as by the inadvertent mixing of seeds during population development, because the populations were developed and selected in the field by the bulk method, from the $F_{2}$ to $F_{5}$ generations (Silva et al. 2018). Silva et al. (2014) evaluated the same BRSMG Madrepérola $\times$ BRS Estilo population as in the present study but in the $\mathrm{F}_{4}$ generation. These authors conducted experiments in two environments, but identified monogenic control for seed darkening in only one of them.

Conversely, both the BRSMG Madrepérola $\times$ BRS Cometa and BRSMG Madrepérola $\times$ BRS Notável populations exhibited phenotypic segregation compatible with monogenic inheritance of the slowdarkening trait. Consequently, these two populations were considered together and also exhibited monogenic segregation. The phenotypic segregation tests performed for each environment identified a segregation pattern similar to that revealed by the joint analysis: BRSMG Madrepérola $\times$ BRS Sublime ( $p$ value ranging from 0.001 to 0.007 ); BRSMG Madrepérola $\times$ BRS Estilo ( $p$ value ranging from 0.001 to 0.004$)$; BRSMG Madrepérola $\times$ BRS Cometa ( $p$ value ranging from 0.057 to 0.102 ); and BRSMG Madrepérola $\times$ BRS Notável ( $p$ value ranging from 0.022 to 0.079 ). The four populations were analyzed together and found not to fit the expected monogenic segregation. Nonetheless, as described below the $S d$-linked molecular markers assayed in the four populations together co-segregated with the slowdarkening trait (Table 4).

\section{Use of the SSR marker PVM02TC116 SSR} for MAS

Due to compromised seed or DNA samples, not all lines within the four populations were assayed for the slow-darkening linked markers (Table 3). In addition, the PVM02TC116 SSR marker was only polymorphic in the BRSMG Madrepérola and BRS Sublime 
Table 3 Segregation for the slow-darkening trait and linked molecular markers in four carioca inbred populations

\begin{tabular}{|c|c|c|c|c|c|c|c|}
\hline Population & $\begin{array}{l}\text { Marker/total } \\
\text { population }\end{array}$ & $\begin{array}{l}\text { Number } \\
\text { of lines }\end{array}$ & $\begin{array}{l}\text { Phenotype/ } \\
\text { genotype }\end{array}$ & $\begin{array}{l}\text { Observed } \\
\text { frequency } \\
\text { (RD:SD) }\end{array}$ & $\begin{array}{l}\text { Expected } \\
\text { frequency } \\
\text { (RD:SD) }\end{array}$ & $\chi^{2}$ & $p$ value \\
\hline \multirow{7}{*}{$\begin{array}{l}\text { BRSMG } \\
\text { Madrepérola } \times \text { BRS } \\
\text { Sublime }\end{array}$} & $\begin{array}{l}\text { Total } \\
\text { population }\end{array}$ & 55 & Phenotype & $39: 16$ & $29: 26$ & 7.29 & 0.007 \\
\hline & PvbHLHp12804 & 46 & Phenotype & $30: 16$ & $24: 22$ & 3.14 & 0.077 \\
\hline & & & Genotype & $29: 17$ & $24: 22$ & 2.18 & 0.139 \\
\hline & Pvsd1158 & 55 & Phenotype & $39: 16$ & $24: 22$ & 7.29 & 0.007 \\
\hline & & & Genotype & $39: 16$ & $24: 22$ & 7.29 & 0.007 \\
\hline & PVM02TC116 & 55 & Phenotype & $39: 16$ & $24: 22$ & 7.29 & 0.007 \\
\hline & & & Genotype & 49:06 & $24: 22$ & 29.2 & 0.001 \\
\hline \multirow{5}{*}{$\begin{array}{l}\text { BRSMG } \\
\text { Madrepérola } \times \text { BRS } \\
\text { Estilo }\end{array}$} & $\begin{array}{l}\text { Total } \\
\text { population }\end{array}$ & 54 & Phenotype & $40: 14$ & $29: 25$ & 9.01 & 0.003 \\
\hline & PvbHLHp12804 & 46 & Phenotype & $33: 13$ & $24: 22$ & 7.06 & 0.008 \\
\hline & & & Genotype & $30: 16$ & $24: 22$ & 3.14 & 0.077 \\
\hline & Pvsd1158 & 50 & Phenotype & $38: 12$ & $27: 23$ & 11.5 & 0.001 \\
\hline & & & Genotype & $37: 13$ & $27: 23$ & 9.70 & 0.002 \\
\hline \multirow{5}{*}{$\begin{array}{l}\text { BRSMG } \\
\text { Madrepérola } \times \text { BRS } \\
\text { Cometa }\end{array}$} & $\begin{array}{l}\text { Total } \\
\text { population }\end{array}$ & 55 & Phenotype & $34: 21$ & $24: 22$ & 1.83 & 0.177 \\
\hline & PvbHLHp12804 & 50 & Phenotype & $30: 20$ & $27: 23$ & 0.73 & 0.395 \\
\hline & & & Genotype & $29: 21$ & $27: 23$ & 0.32 & 0.570 \\
\hline & Pvsd1158 & 54 & Phenotype & $33: 21$ & $29: 25$ & 1.19 & 0.275 \\
\hline & & & Genotype & $32: 22$ & $29: 25$ & 0.67 & 0.413 \\
\hline \multirow{5}{*}{$\begin{array}{l}\text { BRSMG } \\
\text { Madrepérola } \times \text { BRS } \\
\text { Notável }\end{array}$} & $\begin{array}{l}\text { Total } \\
\text { population }\end{array}$ & 56 & Phenotype & $36: 20$ & $30: 26$ & 2.58 & 0.108 \\
\hline & PvbHLHp12804 & 53 & Phenotype & $33: 20$ & $28: 25$ & 1.89 & 0.168 \\
\hline & & & Genotype & $33: 20$ & $28: 25$ & 1.89 & 0.168 \\
\hline & Pvsd1158 & 54 & Phenotype & $34: 20$ & $29: 25$ & 1.86 & 0.172 \\
\hline & & & Genotype & $34: 20$ & $29: 25$ & 1.86 & 0.172 \\
\hline
\end{tabular}

RD, Regular darkening; SD, slow darkening

population. The cultivars BRSMG Madrepérola, BRS Estilo, BRS Cometa and BRS Notável exhibited a 175-bp allele, whereas BRS Sublime exhibited a 191-bp allele for the PVM02TC116 marker. The lack of detection of polymorphism for the PVM02TC116 marker between BRSMG Madrepérola and BRS Estilo, BRS Cometa and BRS Notável indicates that this marker lacks broad utility for MAS. Moreover, PVM02TC116 did not fit the expected segregation in the BRSMG Madrepérola $\times$ BRS Sublime population. In addition, weak co-segregation (2:14:0:35) and high genetic distance $(32.7 \mathrm{cM})$ of the PVM02TC116 marker with the slow-darkening phenotype in this population further limits its utility. Similarly, Alves (2014) observed that only a small amount of phenotypic variation (2\%) was explained by the PVM02TC116 marker in a population derived from a cross between BRSMG Madrepérola and the advanced line RP-2. Although Couto et al. (2010) observed that the PVM02TC116 marker co-segregated perfectly with the slow-darkening trait segregating in the BRSMG Madrepérola $\times$ BRSMG Majestoso population, we do not recommend using PVM02TC116 for MAS of the slow-darkening trait in carioca beans given the negative results obtained in the present study and in that conducted by Alves (2014). 


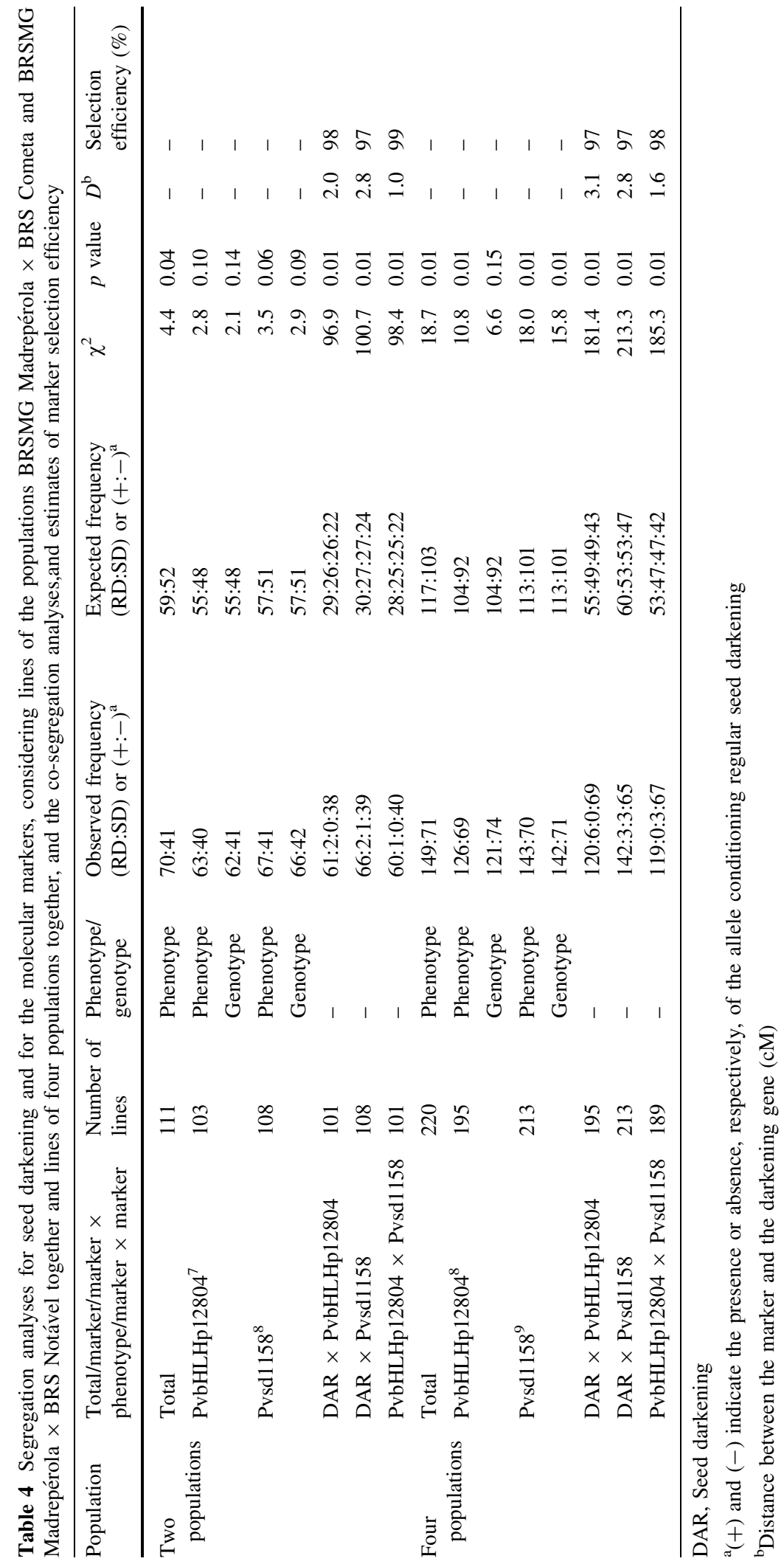


Use of the SSR marker PVSD-1158 for MAS

The marker Pvsd-1158 exhibited polymorphism in all four inbred populations. BRSMG Madrepérola exhibited the 120-bp allele and BRS Estilo, BRS Cometa, BRS Notável, and BRS Sublime exhibited the 130-bp allele; these are the same size as the alleles reported by Felicetti et al. (2012). Interestingly, Alves (2014) did not observe a polymorphism for the Pvsd-1158 marker between BRSMG Madrepérola and the regular darkening line RP-2, which supports the benefit from developing additional markers (in our case a SNP marker) to expand MAS capability and to continue working towards fine-mapping of the $s d$ gene.

The segregation obtained for Pvsd-1158 was similar to the phenotypic segregation, adjusting the monogenic segregation in the populations BRSMG Madrepérola $\times$ BRS Cometa, BRSMG Madrepérola $\times$ BRS Notável and in these two populations together (Table 3). The Pvsd-1158 marker was highly predictive (97\%) of the slow-darkening phenotype as only three individuals of the 108 assayed were putative recombinants. The linkage analysis indicated an estimated distance of $2.8 \mathrm{cM}$ between the Pvsd- 1158 and the gene conditioning the slow-darkening trait. This distance is similar to the mean $0.4 \mathrm{cM}$ linkage distance estimated by Felicetti et al. (2012) between Pvsd 1158 and $S d$ across three pinto bean populations. Considering the four populations together, the distance was $2.8 \mathrm{cM}$ and the selection efficiency was also high (97\%). This marker had not previously been tested for carioca types. However, the Pvsd-1157 marker, which is located near Pvsd-1158, was tested in four lines of carioca seeds with slow darkening that were derived from the pinto line 1533-15 and originating from the breeding program of the University of Saskatchewan (Canada); Pvsd-1157 exhibited the allele compatible with slow darkening in all cases (Felicetti et al. 2012). This tight linkage confirms that Pvsd-1158 will have utility for MAS of the slowdarkening trait in the carioca dry bean market class and also indicates that the $S d$ gene described by JunkKnievel et al. (2008) in the pinto market class must be the same gene as that described in carioca by Silva et al. (2008). That the same gene locus influences the slow-darkening trait in both pinto and carioca market classes is further supported by successful introgression of the $s d$ allele from pinto to carioca in the University of Saskatchewan breeding program. To validate these findings, we suggest that a test of allelism be carried out on the cross between these lines to check if there is phenotypic segregation in the $F_{2}$ generation for seed darkening. If the gene is the same, there should not be individuals in the $F_{2}$ generation with regular seed darkening.

\section{Use of the SNP marker PvbHLHp12804 for MAS}

The SNP marker PvbHLHp12804 was polymorphic between BRSMG Madrepéola and the other four parents. BRSMG Madrepérola exhibited allele 2 (AFAM fluorescence) and the other parents exhibited allele 1 (G-VIC fluorescence). The PvbHLHp12804 SNP exhibited monogenic Mendelian segregation in the same two populations that exhibited the Pvsd- 1158 marker and was tightly linked $(2.0 \mathrm{cM})$ with the slowdarkening trait in both the BRSMG Madrepérola $\times$ BRS Cometa and BRSMG Madrepérola $\times$ BRS Notável populations (Tables 3, 4). Co-segregation analysis indicated that only three of the 103 lines assayed were putative recombinants between the SNP marker and the gene conditioning slow darkening. When the four populations were considered together, the distance was $3.1 \mathrm{cM}$ and the selection efficiency was also high (97\%). Co-segregation analysis between Pvsd-1158 and PvbHLHp12804 in the two populations together and in the four populations together indicated that just one of 101 lines was recombinant $(1.0 \mathrm{cM})$ and just three of 189 lines were recombiant $(1.6 \mathrm{cM})$, respectively, confirming that there was only a small distance between these markers.

All samples of the four slow-darkening carioca parental lines developed at the University of Saskatchewan, which were screened with the PvbHLHp12804 KASP assay, were positive for the slow-darkening allele. All other regular-darkening carioca material, including the parental line A285, possessed the alternate, regular-darkening allele. Furthermore, all of the samples tested from the 14 advanced slowdarkening lines derived from these crosses also tested positive for the slow-darkening KASP marker allele.

In this case, determining genetic distance was difficult in the absence of an advanced carioca population segregating for the slow-darkening trait. However, given the number of crosses made and the number of advanced lines produced, the lack of any recombinants being detected in the breeding program suggests a very high degree of linkage between the 
PvbHLHp12804 SNP and the slow-darkening trait. Given that the slow-darkening trait was most likely acquired from the slow-darkening advanced pinto breeding line SC11743-3, the PvbHLHp12804 KASP was used to screen a pinto recombinant inbred line population segregating for the same SC11743-3derived slow-darkening trait. A total of 114 lines from the CDC Pintium $\times 1533-15$ population were screened and no recombinants were found. This complete co-segregation of PvbHLHp12804 SNP, which defines an allele of the $P$ gene, with the slowdarkening trait in the University of Saskatchewan materials warrants continued work to investigate whether $P$ may also be involved in post-harvest seed coat darkening.

\section{Conclusions}

In summary, the gel-based SSR Pvsd-1158 and fluorescent-based SNP PvbHLHp12804 co-dominant markers are closely linked to the slow-darkening trait in the carioca dry bean market class. These markers are highly efficient at identifying slow seed darkening and can be used routinely in MAS. They could also be used in common bean breeding programs at different scales of genotype evaluation, for early selection in the initial generations, for introgressing the recessive allele $s d$ by backcrossing and for simultaneous MAS for various traits in a single generation.

\section{References}

Alvares RC, Silva FC, Melo LC, Melo PGS, Pereira HS (2016) Estimation of genetic parameters and selection of highyielding, upright common bean lines with slow seed-coat darkening. Genet Mol Res 15:gmr15049081

Alves FC (2014). Eficiência da seleção assistida por marcadores moleculares para o escurecimento tardio de grãos em feijão-comum. 2014. 64 f. Dissertação (Mestrado em Genética e Melhoramento de Plantas), Universidade Federal de Lavras, Lavras

Araújo LCA, Ramalho MAP, Abreu AFB (2012) Estimates of genetic parameters of late seed-coat darkening of carioca type dry beans. Ciência Agrotecnol 36:156-162

Bett KE, Vandenberg A, Banniza S, Lu Q, Barlow B, Ife S (2014) CDC WM-2 common bean. Can J Plant Sci 94:469-471

Carneiro MS, Vieira ML (2002) Mapas genéticos em plantas. Bragantia 61:89-100
Carneiro JES, Abreu AFB, Ramalho MAP, Paula Júnior TJ, Del Peloso MJ, Melo LC, Pereira HS, Pereira Filho IA, Martins M, Vieira RF, Martins FAD, Coelho MAO, Carneiro PCS, Moreira JAA, Santos JB, Faria LC, Costa JGC, Teixeira H (2012) BRSMG Madrepérola: common bean cultivar with late-darkening Carioca grain. Crop Breed Appl Biotechnol 4:281-284

Couto KR, Santos JB, Ramalho MAP, Silva GS (2010) Identificação de marcadores moleculares microssatélites relacionados ao escurecimento de grãos em feijão. Pesqui Agropecu Bras 45:1268-1274

Cruz CD (2013) Genes: a software package for analysis in experimental statistics and quantitative genetics. Acta Sci Agron 35:271-276

Doyle JJ, Doyle JL (1990) Isolation of plant DNA from freshtissue. Focus 12:13-15

Elsadr HT, Wright LC, Pauls KP, Bett KE (2011) Characterization of seed coat post-harvest darkening in common bean (Phaseolus vulgaris L.). Theor Appl Genet 123:1467-1472

Embrapa Arroz e Feijão (2018) Home page. https://www. embrapa.br/arroz-e-feijao/produtos-processos-e-servicos. Accessed 22 Feb 2018

Faria LC, Del Peloso MJ, Melo LC, Costa JGC, Rava CA, Díaz JLC, Faria JC, Silva HT, Sartorato A, Bassinelo PZ, Trovo BF (2008) BRS Cometa: a carioca common bean cultivar with erect growth habit. Crop Breed Appl Biotechnol 2:167-169

Felicetti E, Song Q, Jia G, Cregan P, Bett KE, Miklas PN (2012) Simple sequence repeats linked with slow darkening trait in pinto bean discovered by single nucleotide polymorphism assay and whole genome sequence. Crop Sci 52:1600-1608

Junk-Knievel DC, Vandenberg A, Bett KE (2007) An accelerated postharvest seed-coat darkening protocol for pinto beans grown across diferent environments. Crop Sci 47:694-702

Junk-knievel DC, Vanderberg A, Bett KE (2008) Slow darkening in pinto bean (Phaseolus vulgaris L.) seed coats is controlled by a single major gene. Crop Sci 48:189-193

Kosambi DD (1944) The estimation of map distances from recombination values. Ann Eugen 12:172-175

McClean PE, Bett KE, Stonehouse R, Lee R, Pflieger S, Moghaddam SM, Geffroy V, Miklas P, Mamidi S (2018) White seed color in common bean (Phaseolus vulgaris) results from convergent evolution in the $\mathrm{P}$ (pigment) gene. New Phytol 219:1112-1123

Melo LC, Del Peloso MJ, Pereira HS, Faria LC, Costa JGC, Díaz JLC, Rava CA, Wendland A, Abreu AFB (2010) BRS Estilo - Common bean cultivar with Carioca grain, upright growth and high yield potential. Crop Breed Appl Biotechnol 10:377-379

Osorno JM, VanderWal AJ, Kloberdanz M, Pasche JS, Schroder S, Miklas PN (2017) A new slow-darkening pinto bean with improved agronomic performance: registration of 'ND-Palomino'. J Plant Regist 12:25-30. https://doi.org/ 10.3198/jpr2017.05.0026cr

Pereira HS, Almeida VM, Melo LC, Wendland A, Faria LC, Del Peloso MJ, Magaldi MCS (2012a) Influência do ambiente em cultivares de feijoeiro-comum em cerrado com baixa altitude. Bragantia 71:165-172 
Pereira HS, Wendland A, Melo LC, Del Peloso MJ, Faria LC, Costa JGC, Nascente AS, Díaz JLC, Carvalho HWL, Almeida VM, Melo CLP, Costa AF, Posse SCP, Souza JF, Abreu AFB, Magaldi MCS, Guimarães CM, Oliveira JP (2012b) BRS Notável: a médium-early-maturing, diseaseresistant Carioca common bean cultivar with high yield potential. Crop Breed Appl Biotechnol 12:220-223

Silva LC, Cruz CD, Moreira MA, Barros EG (2007) Simulation of population size and genome saturation level for genetic mapping of recombinant inbred lines (RILs). Genet Mol Biol 30:1101-1108

Silva GS, Ramalho MAP, Abreu AFB, Silva FB (2008) Genetic control of early grain darkening of carioca common bean. Crop Breed Appl Biotechnol 8:299-304

Silva FC, Melo PGS, Pereira HS, Melo LC (2014) Genetic control and estimation of genetic parameters for seed-coat darkening of carioca beans. Genet Mol Res 13:6486-6496

Silva FC, Pereira HS, Melo PGS, Melo LC (2018) Seleção de genitores e populações segregantes de feijoeiro-comum com alto potencial agronômico e escurecimento lento dos grãos. Pesqui Agropecu Trop 48:75-82

Singh SP, Téran H, Lema M, Dennis MF, Hayes R (2006) Registration of slow darkening pinto bean germplasm line SDIP-1. Crop Sci 46:2726-2727

Siqueira BS, Pereira WJ, Batista K, Oomah BD, Fernandes KF, Bassinelo PZ (2014) Influence of storage on darkening and hardening of slow- and regular-darkening carioca bean (Phaseolus vulgaris L.) genotypes. J Agric Stud 2:87-104

Wendland A, Pereira HS, Faria LC, Souza TLPO, Del Peloso MJ, Costa JGC, Díaz JLC, Magaldi MCS, Almeida VM, Carvalho HWL, Melo CLP, Costa AF, Abreu AFB, Melo LC (2018) BRS sublime: common bean cultivar with carioca grain, resistance to angular leaf spot and high nutritional quality. Crop Breed Appl Biotechnol 18:440-445

Publisher's Note Springer Nature remains neutral with regard to jurisdictional claims in published maps and institutional affiliations. 